\title{
Prognostic value of immunohistochemical expression of HER-2/neu in patients with lung carcinoma
}

\author{
Biljana Ilievska Poposka ${ }^{1}$, Snezana Smickova ${ }^{2}$, \\ Simonida Jovanovska Crvenkovska ${ }^{2}$, Beti Zafirova Ivanovska ${ }^{3}$, \\ Tome Stefanovski ${ }^{4}$, Gordana Petrusevska ${ }^{5}$
}

\author{
${ }^{1}$ Institute for Lung Diseases and Tuberculosis, ${ }^{2}$ Institute for Radiology and Oncology, \\ ${ }^{3}$ Institute for Epidemiology, ${ }^{4}$ Clinic for Pneumology and Allergology, ${ }^{5}$ Institute for Pathology, \\ ${ }^{5}$ Medical Faculty, University of "Sv. Kiril and Metdoij", Skopje, Republic of Macedonia
}

\begin{abstract}
Background. The amplification and the overexpression of the Her-2/neu gene have been shown in certain human tumours and are postulated to be important in human carcinogenesis. In this study we evaluated the expression of HER-2/neu gene in patients with lung carcinoma (LC) and assessed its prognostic significance.

Patients and methods. HER-2/neu expression was determined in 127 LC patients using immunohistochemistry (IHC) performed on paraffin-embedded section - Hercep Test ${ }^{T M}$ (DAKO).

Results. The overall HER-2/neu expression was seen in 36 (28.35\%) of 127 LC patients. According to the histological type, HER-2/neu overexpression was detected in 12 patients with adenocarcinomas (60\%), in 19 patients with squamous cell carcinomas (31.14\%), in 4 patients with small cell-lung carcinomas (10\%) and in 1 patient with other carcinomas (16.66\%). Only in patients with small cell-lung carcinomas HER-2/ neu overexpression was in correlation with the stage of the disease $(p<0.001)$. The patients with HER-2/neu positive expression were associated with a significantly shorter survival compared with those who were HER-2/neu negative (log rank, $p<0.002$ ).

Conclusions. These observations suggest that HER-2/neu positivity may serve as a prognostic indicator in patients with LC. HER-2/neu plays a role in identifying patients at risk for the shortened survival, who may benefit from a more aggressive therapy.
\end{abstract}

Key words: HER-2/neu, lung cancer; immunohistochemisty; survival

Received 22 July 2008

Accepted 31 July 2008

Correspondence to: Biljana Ilievska Poposka, M.D., M.Sc, Institute for Lung Disease and Tuberculosis, Vodnjanska, 17, 1000 Skopje, Macedonia. Phone: +38970 234436; 003892 3147510; Fax: +3892 229166; E-mail: biljana_ili@hotmail.com

\section{Introduction}

Lung cancer is the leading cause of cancer death worldwide with a still increasing incidence. ${ }^{1,2}$ Despite new chemotherapeutic 
drugs, improvement in surgical techniques, histological classification, and staging procedures, lung cancer survival has not greatly improved over the past 20 years. The cure rate remains less than $15 \%{ }^{3}$ Recent advances in biology and molecular biology identified the relationship between specific gene alterations and clinical behaviour of lung cancers. A number of studies have been performed to assess the prognostic role of tumour-suppressor genes and protooncogenes.

HER-2/neu (also known as c-erbB2) oncogene is the second member of the epidermal growth factor of the receptor family. ${ }^{4}$ The HER-2/neu dominant gene is localized in normal human cells as a singular copy on the long arm (q21) of chromosome $17 .^{5}$ This gene codes for a $185-\mathrm{kDa}$ receptor-type tyrosine protein kinases (p185neu or c-erbB2), similar to EGF-R. ${ }^{6-8}$ This 1255 aminoacid transmembrane glycoprotein is composed of there domains: extracellular factor-binding domain, transmembrane domain and intracellular domain with a tyrosine kinase activity. ${ }^{9}$ When an EGF-like ligand (there is no known specific ligand for HER-2/neu) binds to a receptor of the EGF-R family, (HER-1, 3 or 4 ) there is a heterodimerisation of this receptor with HER$2 .{ }^{10}$ HER-2 is necessary for the regulation of the normal cell growth and differentiation, and can be associated with multiple signal transduction pathways. ${ }^{11}$ The amplification of the HER-2 gene leads to an overexpression of the receptor and protein product $\mathrm{p}$ 185, which could be implicated in the development of many types of tumours. HER-2/neu is expressed in a wide variety of human epithelial malignancies, including breast, ovary, salivary gland, gastrointestinal tract, prostate, lung, kidney, liver. ${ }^{12-18}$ This suggests that HER-2/neu overexpression probably plays a critical role in the development and progression of human cancers.
The aim of this study was to determine the correlation between HER-2/neu expression and clinicopathological features in patients with lung carcinoma and to assess its relation to the survival.

\section{Patients and methods}

\section{Patients and tissue samples}

Our study population consisted of 127 patients with lung carcinoma (LC) diagnosed between January 2004 and December 2006 in the Institute for Lung Diseases and Tuberculosis, Skopje, Macedonia. Patients included 115 men and 12 women. Their age ranged from 37 to 87 years old (mean, 58.49 \pm 8.15 ); $80.10 \%$ of them were smokers.

The diagnosis of LC was established by the histological examination of tissue samples obtained during the bronchoscopy in 120 patients $(94.48 \%)$ or by surgery in 7 patients (5.51\%). All histological analysis of the tumour tissue and immunohistochemistry (ICH) were performed at the Institute for Pathology, Medical Faculty, Skopje. The histological type and degree of differentiation were assigned according to World Health Organization criteria. ${ }^{19}$ Tumours included 40 small-cell lung carcinomas (SCLC) and 87 non-small-cell lung carcinomas (NSCLC) - 20 adenocarcinomas, 61 squamous cell carcinomas and 6 tumours assigned as "others" (bronchoalveolare, large cell carcinomas, nondifferentiated carcinomas). For the histological differentiation, well moderately and poorly differentiated tumours were graded as grade 1, 2 and 3, respectively.

According to the International Staging System for Lung Cancer, ${ }^{20} 87$ NSCLC patients were divided in: 3 patients with IB stage $(3.44 \%), 1$ patient with IIA stage (1.14\%), 11 patients with stage IIB (12.64\%), 22 patients with stage IIIA (25.28\%), 34 patients with stage IIIB (39.08\%) and 16 pa- 
tients with stage IV (18.39\%). The patients with SCLC were staging in 23 patients with limited diseases (57.5\%) and 17 patients with extensive diseases (42.5\%).

One hundred and twenty patients were treated with chemotherapy and/or radiotherapy at the Institute for Radiotherapy and Oncology, Medical Faculty, Skopje. Seven patients underwent surgery first, and after that they were treated with radiotherapy. All patients were followed up regularly in a time frame of 2 to 3 months. The patients were followed up from 1 to 48 months (median 24 months). At the time of the last follow-up 114 patients (89.76\%) had died and 13 patients (10.23\%) were still alive. The survival time was calculated from the date of histological diagnosis to the date of death or last follow-up.

\section{Immunohistochemistry}

HER-2/neu oncogene expression was determined by immnunohistochemical staining with Hercep Test ${ }^{\mathrm{tm}}$ (DAKO, Copenhagen, Denmark). After bronchoscopy or surgery, fresh tumour tissue specimens were immediately formalin fixed. Section $4 \mu \mathrm{m}$ thick were cut from tissue blocks, placed on glass slides and exposed to xylene 3 times for $5 \mathrm{~min}$ each. Tissues were hydrated in decreasing concentrations of ethanol $(100 \%$, $95 \%$ and $70 \%$ for $2 \mathrm{~min}$ each) and rinsed in distilled water. Slides were washed in PBS (Phosphate Buffer Saline) for $20 \mathrm{~min}$. After excess liquid was blotted off, slides were heated at $120^{\circ} \mathrm{C}$ in $0.01 \mathrm{M}$ citrate buffer (pH 6.0) to expose the HER2 protein antigen. The endogene peroxidase activity was blocked by Peroxidase Blocking Reagent for $5 \mathrm{~min}$. The rabbit antihuman HER2 protein polyclonal antibody was applied for $2 \mathrm{~h}$ at room temperature. Slides were rinsed with PBS, and peroxidase-conjugated antirabbit antibody was added for $30 \mathrm{~min}$ at room temperature. Diaminobenzidine solution was added to achieve specific staining. Slides were counterstained with hematoxylin.

The evaluation of HER-2/neu immunoreactivity was performed according to the DAKO protocol for the Hercept Test ${ }^{\mathrm{tm}}$, with minor modifications. Only membrane staining was considered positive, whereas cytoplasmatic staining was considered nonspecific. Immunostaging was classified as follows: score 0: no staining at all or membrane staining in $<10 \%$ neoplastic cells; score $1+$ : a faint/barely appreciable membrane staining is detected in $>10 \%$ of the tumour cells; the cells are only stained in part of their membrane; score 2+: a with weak to moderate complete membrane staining is observed in $>10 \%$ of the tumour cells; score $3+$ : a strong immunoreactivity of the entire membrane is observed in $>10 \%$ of the tumours cells. Tumours classified as 0 or $1+$ were considered "negative", and those scored $2+$ or $3+$ were classified as "positive".

\section{Statistical Analysis}

Statistical significances of the relationship between clinicopathological data and IHC were assessed by a chi-square test. The Fisher's exact test was used when the frequency of a cell in a $2 \times 2$ table was $<5$. The overall survival rate was calculated using the Kaplan-Meier method. The difference was considered to be statistically significant at $\mathrm{p}<0.05$.

\section{Results}

Figure 1 shows the staining of HER-2/neu in adenocarcinoma using immunohistochemical methods. The dark brown colour denotes positive staining located predominantly at the cell membrane.

Quantitative data are shown in Table 1, which summarizes expressions of HER-2/neu 
Table 1. The relationship between the expression of the HER-2/neu and clinicopathological features in patients with lung cancer

\begin{tabular}{|c|c|c|}
\hline Features (n) & HER-2/neu + n (\%) & $\mathrm{p}$ Value \\
\hline \multicolumn{3}{|l|}{ Sex } \\
\hline Male (115) & $34(29.56 \%)$ & \\
\hline Female (12) & $2(16.66 \%)$ & NS \\
\hline \multicolumn{3}{|l|}{ Age } \\
\hline$\leq 65(90)$ & $25(27.77 \%)$ & \\
\hline$>65(37)$ & $11(29.72 \%)$ & NS \\
\hline \multicolumn{3}{|l|}{ Smoking history } \\
\hline Smoker $\quad$ (103) & 27 (26.21\%) & \\
\hline Nonsmoker (24) & $9(37.5 \%)$ & NS \\
\hline \multicolumn{3}{|l|}{ Performans status } \\
\hline WHO 0 & $2(7.40 \%)$ & \\
\hline WHO 1 (79) & $26(32.91 \%)$ & \\
\hline WHO 2 (11) & $2(18.18 \%)$ & \\
\hline WHO 3 & $6(66.66 \%)$ & \\
\hline WHO 4 & $0(0 \%)$ & $\mathrm{p}<0.006$ \\
\hline \multicolumn{3}{|l|}{ Tumour type } \\
\hline SCLC $(40)$ & $4(10.0 \%)$ & \\
\hline NSCLC (87) & $32(36.78 \%)$ & $\mathrm{p}<0.001$ \\
\hline \multicolumn{3}{|l|}{ Differentiation } \\
\hline Well & $2(66.66 \%)$ & \\
\hline Moderate (55) & $14(25.45 \%)$ & \\
\hline Poorly (69) & $20(28.98 \%)$ & NS \\
\hline \multicolumn{3}{|l|}{ Stage (NSCLC) } \\
\hline I B (3) & $0(0 \%)$ & \\
\hline II A & $0(0 \%)$ & \\
\hline II B (11) & $4(36.36 \%)$ & \\
\hline III A (22) & $7(31.81 \%)$ & \\
\hline III B (34) & $11(32.35 \%)$ & \\
\hline IV $\quad(16)$ & $10(62.5 \%)$ & NS \\
\hline \multicolumn{3}{|l|}{ Stage (SCLC) } \\
\hline Limited (23) & $0(0 \%)$ & \\
\hline Extensive (17) & $4(23.52 \%)$ & $\mathrm{p}<0.001$ \\
\hline Total (127) & $36(28.35 \%)$ & \\
\hline
\end{tabular}

Note: statistical analysis was performed using $\mathrm{x}^{2}$ test and Fisher exact test

in 127 LC patients with different clinicopathological features.

HER-2/neu immunoreactivity $(3+/ 2+)$ was detected in 36 of 127 lung cancers cases $(28.35 \%)$. Fifteen tumours (11.81\%) showed strong HER-2/neu immunoreactivity $(3+)$, while twenty one $(16.54 \%)$ tumours were moderately immunoreactive
$(2+)$. Ninety-one cases $(71.65 \%)$ were considered negative; 81 cases were classified as score $0(63.78 \%)$ and 10 cases as score $1+(7.87 \%)$.

As seen in Table 1, no statistically significant correlation was found between the frequency of HER-2/neu protein product expression and some clinicopathological 


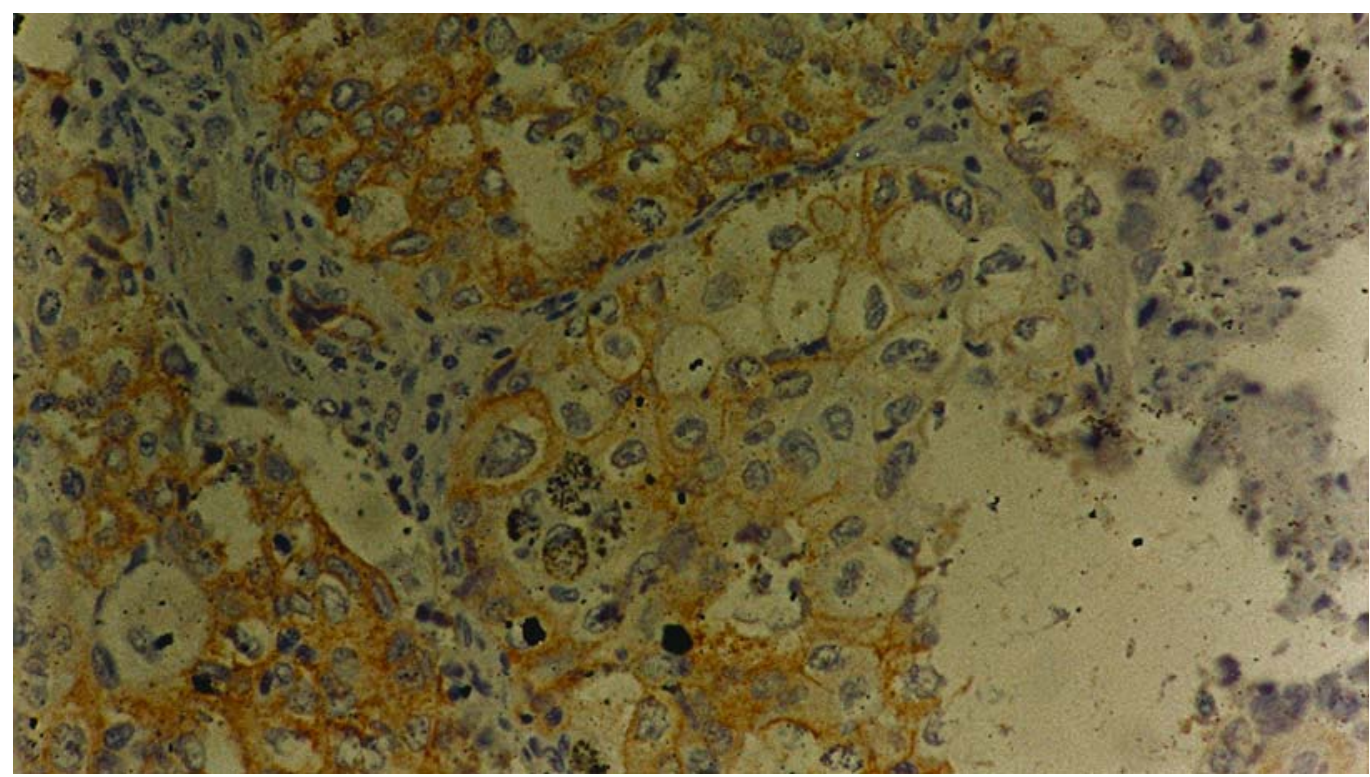

Figure 1. Immunohistochemical staining of HER-2/neu overexpression in lung adenocarcinoma (strong staining $3+$ ).

features under the study including sex, age, smoking history and tumour differentiation (well, moderately and poorly). We found the correlation between HER-2/neu expression and performance status $\left(\mathrm{x}^{2}=14.1 ; \mathrm{p}<0.006\right)$. We also obtained the significant differences in HER-2/neu expression between SCLC and NSCLC $(\mathrm{p}<0.001)$. Among the NSCLC's HER-2/neu expression was found in 12 of $20(60 \%)$ adenocarcinomas, in 19 of $61(31.14 \%)$ squamous cell carcinomas, and in 1 of $6(16.66 \%)$ "other" carcinomas (Table $2)$. The difference in the expression rate between the adenocarcinomas and the other groups was highly significant $\left(x^{2}=17.13\right.$; $\mathrm{p}<0.0001)$. Eight patients $(66 \%)$ with HER$2 /$ neu positive adenocarcinomas showed strong immunoreactivity $(3+)$.

In NSCLC patients HER-2/neu expression was not in correlation with the stage of the diseases. But, there was a significant difference in HER-2/neu expression between SCLC patients with limited and extensive diseases (Fisher exact test $\mathrm{p}<0.001$ ).

We found that the expression of HER-2/ neu protein was associated with a signifi- cant short survival in LC patients. The 24months survival rates of patients with HER2/neu overexpresssion and those without were $21.97 \%$ and $2.77 \%$, respectively (Figure 2) with a statistical significant difference (log-rank Test $=-3.06 ; \mathrm{p}=0.002)$.

\section{Discussion}

Since HER-2/neu proto-oncogene has been originally identified, its overexpression was detected in various types of cancers, first of all in those with epithelial origin. ${ }^{21}$ HER-2/neu expression is associated mainly with high-grade breast carcinoma and considered an important prognostic factor for adverse outcome in node positive breast cancer. ${ }^{13}$ In lung cancer studies, HER-2/neu expression varies depending on the histological classification of the tumours. ${ }^{4,10,22-24}$ Her-2/neu expression was reported in 13$80 \%$ in adenocarcinomas, ${ }^{17,22,24}$ in $2-45 \%$ in squamous cell carcinomas, $15,16,18$ in $0-20 \%$ in large-cell carcinomas ${ }^{23}$ and in $13-31 \%$ in small cell lung carcinomas. ${ }^{4,25,26}$ 
Table 2. HER-2/neu expression in different histological type of lung cancer

\begin{tabular}{lllrlll}
\hline Histological type & No of cases & \multicolumn{6}{l}{ Level of expression } & & \\
\cline { 3 - 7 } & & +++ & ++ & + & - & \% positive \\
\hline SCLC & 40 & 2 & 2 & 2 & 34 & 10.0 \\
Squamous cell cacinoma & 61 & 5 & 14 & 3 & 39 & 31.14 \\
Adenocarcinoma & 20 & 8 & 4 & 5 & 3 & 60.0 \\
Others & 6 & 0 & 1 & 0 & 5 & 16.6 \\
\hline
\end{tabular}

* -: no detectable HER-2/neu expression; +,++, +++: faint, weak and strong expression, respectively

We observed HER-2/neu overexpression in 36 of 127 patients with lung carcinoma (28.25\%). The overexpression was more frequent in NSCLC (36.78\%) than in the SCLC $(10.0 \%)$. The patients with adenocarcinoma showed the highest incidence of positive findings (60\%), with the biggest number of strong reactivity patterns (53.33\%). This observation concurs with the findings of Shi et al., Harpole et al., Pellegriniet et al., Hsieh et al. and others. $8,17,27,28$

The techniques used to detect HER-2/ neu expression might be one of the potential sources of biases. HER-2/neu protein overexpression is most often measured by IHC using one of several monoclonal antibodies, and the gene expression is measured most often by fluorescence in situ hybridization (FISH) for clinical studies. ${ }^{5}$ Immunohistochemical results can vary according to the primary used antibody, dilution of the antibody and tissue conservation. Moreover, this technique is semiquantitative and standards for positive or negative specimen vary between studies making difficult the direct comparison of studies.

In this study we did not find any correlation between HER-2/neu overexpression and the pathologic stage of disease in patients with NSCLC. Even our results showed very low HER-2/neu overexpression in patients with SCLC, we found significant differences of HER-2/neu overexpression between SCLC patients with limited and extensive diseases: HER-2/neu overexpression was seen only in patients with the extensive disease (Fisher exact test $\mathrm{p}<0.05$ ). Tateishi et al. ${ }^{22}$ reported a higher positivity for HER2/neu in Stage III-IV disease with a poor influence on the prognosis. Similarly, Osaki et $a .^{29}$ reported increased serum levels of HER-2/neu in Stage IIIB cases. However, the comparison among different studies is difficult due to a consistent lack of balance in the histotype and the stage distribution from one study to another.

Although HER-2/neu protein expression is widely studied in lung carcinoma, its prognostic role remains uncertain. Even several investigators reported that HER-2/ neu immunostaining adversely affects the prognosis and the survival in LC patients, especially NSCLC patients, ${ }^{17,18,22,23,30}$ some large studies did not find any prognostic implication for HER-2/neu overexpression. ${ }^{31-33}$ There are many studies showing adverse outcomes among patients with breast and ovarian cancers overexpressing this oncogene. Besides, the overall survival rate and time to relapse for those patients with HER-2/neu overexpression is shorter than those lacking the overexpression. ${ }^{13,21,34}$ Our results show that patients with HER-2/neu positive tumours had a significantly decreased survival opposite to patients with HER-2/neu negative tumours. After 24 months, only one patient from the group who were HER$2 /$ neu positive was still alive, in comparison with 20 patients from the group who were HER-2/neu negative.

There are studies which have shown that HER-2/neu overexpression is associated with intrinsic chemoresistance of NSCLC. ${ }^{35}$ 


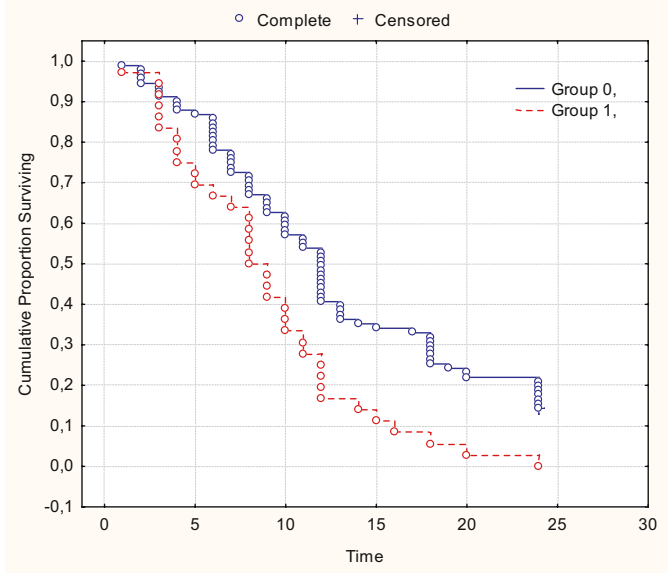

Figure 2. 24-month survival of a patient with lung cancer as a function of absence (solid line) or presence (dashed line) of HER-2/neu overexpression.

Thus, HER-2/neu overexpression may play a role as a predictive factor of response to therapy in patients with LC, who may be candidates for adjuvant therapeutic modalities and the gene therapy possibly improving the overall survival.

\section{Conclusions}

In conclusion, HER-2/neu expression detected in LC is a negative predictor of the survival. Immunohistochemical stainig of Her-2/neu may aid in defining a subpopulation of patients with LC whose tumours may behave more aggressively. In addition, focused adjuvant therapeutic modalities and gene therapies might improve the overall survival in these patients expressing the poor prognostic immunohistochemical marker.

\section{References}

1. Silverberg E, Lubera JA. Cancer statistics. CA Cancer J Clin 1988; 38: 5-22.

2. Evans WK. Rationale for the treatment of nonsmall cell lung cancer. Lung Cancer 1993; 9(Suppl 2): S5-14.
3. Travis WD, Lubin J, Ries L, Devesa S. United States lung carcinoma incidence trends: declining for the most histologic types among males, increasing among females. Cancer 1996; 77: 2464-70.

4. Potti A, Willardson J, Forseen C, Ganti AK, Koch M, Hebert B, et al. Predictive role of HER-2/neu overexpression and clinical features an initial presentation in patients with extensive stage small cell lung carcinoma. Lung Cancer 2002; 36: 257-61.

5. Klijanienko J, Couturier J, Galut M, El-Naggar A, Maciorowski Z, Padoy E, et al. Detection and quantitation by fluorescence in situ hybridization (FISH) and image analysis of Her-2/neu gene amplification in breast cancer fine-needle samples. Cancer 1999; 87: 312-8.

6. Carraway KL 3rd, Cantley LC. A neu acquaintance for ErbB3 and ErbB4: a role for receptor heterodimerization in growth signaling. Cell 1944; 78: 5-8.

7. Fernandes A, Hamburger AW, Gerwin BI. ErbB-2 kinase is required for constitutive STAT 3 activation in malignant human lung epithelial cells. Int J Cancer 1999; 83: 564-70.

8. Shi D, He G, Cao S, Pan W, Zhang HZ, Yu D, et al. Overexpression of the c-erbB-2/neu-encoded p185 protein in primary lung cancer. Mol Carcinog 1992; 5: 213-8.

9. Akiyama T, Sudo C, Ogawara H, Toyoshima K, Yamamoto T. The product of human c-erbB-2 gene: A 185-kilodalton glycoprotein with tyrosine kinase activity. Science 1986; 42: 1644-6.

10. Meert AP, Martin B, Paesmans M, Berghmans T, Mascaux C, Verdebout J-M, et al. The role of HER2/neu expression on the survival of patients with lung cancer: a systematic review of the literature. Br J Cancer 2003; 89: 959-65.

11. Hung MC, Lau YK. Basic science of HER-2/neu: a review. Semin Oncol 1999; 26(Suppl 12): 51-9.

12. Brodowicz T, Wiltschke C, Budinsky AC, Krainer M, Steger GG, Zielinski CC. Soluble HER-2/neu neutralizes biologic effects of anti-HER/2neu antibody on breast cancer cells in vitro. Int J Cancer 1997; 73: 875-9.

13. Wright C, Angus B, Nisholson S, Sainsbury JR, Cairns JC, Gullick WJ, et al. Expression of the c-erbB-2 oncoprotein: a prognostic indicator in human breast cancer. Cancer Res 1989; 49: 2087-90.

14. Jing X, Kakudo K, Murakami M, Nakamura Y, Nakamura M, Yokoi T, et al. Intraductal spread of invasive breast carcinoma has a positive correlation with c-erb B-2 overexpression and vascular invasion. Cancer 1999; 86: 439-48. 
15. Agus DB, Bunn PA Jr, Franklin W, Garcia M, Ozols RF. HER-2/neu as a therapeutic target in non-small cell lung cancer, prostate cancer, and ovarian cancer. Semin Oncol 2000; 27: 92-100.

16. Selvaggi G, Scagliotti GV, Torri V, Novello S, Leonardo E, Cappia S, et al. HER-2/neu overexpression in patients with radically resected nonsmall-cell lung carcinoma. Impact on long-term survival. Cancer 2002; 94: 2669-74.

17. Harpole DH, Marks JR, Richards WG, Herndon JE, Sugarbaker DJ. Localized adenocarcinoma of the lung: oncogene expression of erbB-2 and p53 in 150 patients. Clin Cancer Res 1995; 1: 659-64.

18. Han H, Landeneau RJ, Santucci TS, Tung MY, Macherey RS, Shackney SE, et al. Prognostic value of immunohistochemical expression of p53, HER$2 /$ neu, and bcl-2 in stage I non-small-cell lung cancer. Hum Pathol 2002; 33: 105-10.

19. WHO. Histological typing of lung tumors. Am J Clin Pathol 1982; 77: 123-36.

20. Mountain CF. Revision in the international system for staging lung cancer. Chest 1997; 111: 1710-7.

21. Slamon DJ, Clark GM, Wong SG, Levin WJ, Ullrich A, McGuire WL. Human breast cancer: correlation of relapse and survival with amplification of the erbB-2/neu oncogene. Science 1987; 235: 177-82.

22. Tateishi M, Ishida T, Mitsudomi T, Kaneko S, Sugimachi K. Prognostic value of c-erbB-2 protein expression in human lung adenocarcinoma and squamous cell carcinoma. Eur J Cancer 1991; 27: 1372-5.

23. Kern JA, Schwartz DA, Nordberg JE, Weiner DB, Greene IM, Torney L, et al. p185 neu expression in human lung adenocarcinomas predicts shortened survival. Cancer Res 1990; 50: 5184-91.

24. Shi D, He G, Cao S, Pan W, Zhang HZ, Yu D, et al. Overexpression of the c-erbB-2/neu-encoded p185 protein in primary lung cancer. Mol Carcinog 1992; 5: 213-8.

25. Micke P, Hengstler JG, Ros R, Bittinger F, Metz T, Gebhard S, et al. C-ERB-2 expression in small-cell lumg cancer is associated with poor prognosis. Int J Cancer 2001; 92: 474-9.

26. Potti A, Ganti AK, Tuchman SA, Sholes K, Lagness E, Koka V, et al. Effect of pesticide exposure on HER-2/neu overexpression seen in patients with extensive stage small cell lung carcinoma. Clin Cancer Res 2003; 9: 4872-6.
27. Pellegrini C, Falleni M, Marchetti A. Cassani B, Miozzo M, Buttitta F, et al. HER-2/neu alterations in non-small cell lung cancer. Clin Cancer Res 2003; 9: $3645-52$.

28. Hsieh CC, Chow KC, Fahn HJ, Tsai CM, Li WY, Huang $\mathrm{MH}$, et al. Prognostic significance of HER$2 /$ neu overexpression in stage 1 adenocarcinoma of lung. Ann Thorac Surg 1998; 66: 1159-64.

29. Ossaki T, Mitsudomi T, Oyama T, Nakanishi R, Yasumoto K. Serum level and tissue expression of c-erB-2 protein in lung adenocarcinoma. Chest 1995; 108: 157-62.

30. Kim YC, Park KO, Kern JA, Park CS, Lim SC, Jang AS, et al. The interactive effect of Ras, HER2, P53 and Bcl-2 expression in predicting the survival of non-small cell lung cancer patients. Lung Cancer 1998; 22: 181-90.

31. Pfeiffer P, Clausen PP, Andersen K. Lack of prognostic significance of epidermal growth factor receptor and oncoprotein p185 HER-2/neu in patients with systemically untreated non-small cell lung cancer: an immunohistochemical study on cryosections. Br J Cancer 1996; 74: 86-91.

32. Pelosi G, Del Curto B, Dell'Orto P, Pasini F, Veronesi G, Spaggiari L, et al. Lack of prognostic implications of HER-2/neu abnormalities in 345stage I non small cell carcinomas and 207 stage I-III neuroendocrine tumours of the lung. Int J Cancer 2004; 113: 101-8.

33. Pastorino U, Andreola S, Tagliabue E, Pezzela F, Incarbone M, Sozzi G, et al. Immunocytochemical markers in stage I lung cancer: relevance to prognosis. J Clin Oncol 1997; 15: 2858-65.

34. Slamon DJ, Godolphin W, Jones LA. Studies of HER-2/neu proto-oncogene in human breast and ovarian cancer. Science 1989; 244: 707-12.

35. Tsai CM, Chang KT, Wu LH, Chen JY, Gazdar AF, Mitsudomi T, et al. Correlation between intrinsic chemoresistance and HER-2/neu gene expression, p53gene mutations, and cell proliferation characteristics in non-small cell lung cancer cell lines. Cancer Res 1996; 56: 206-9. 